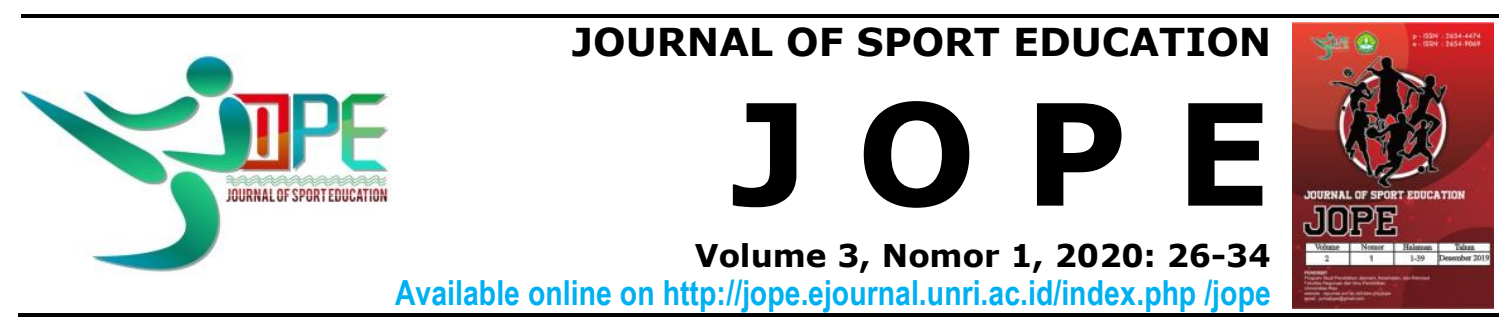

\title{
Sistem pembinaan prestasi atlet cabang olahraga menembak perbakin provinsi riau
}

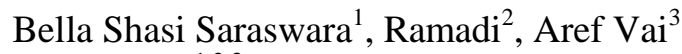 \\ ${ }_{1,2,3}$ Universitas Riau \\ bellashaskii@gmail.com¹, MrRamadi59@gmail.com², aref.vai@lecturer.unri.ac.id ${ }^{3}$ \\ Received: 28 Agustus 2020; Revised: 19 Oktober 2020; Accepted: 31 Oktober 2020 \\ doi) http://dx.doi.org/10.31258/jope.3.1.26-34
}

\begin{abstract}
Abstrak
Penelitian ini bertujuan untuk mengetahui sistem pembinaan prestasi atlet cabang olahraga menembak di Provinsi Riau. Metode Penelitian yang digunakan adalah deskriptif kuantitatif subjek penelitian yang berjumlah 14 orang. Instrumen yang digunakan berupa teknik observasi, wawancara dan angket yang dilakukan secara daring. Dari hasil penelitian yang sudah dilakukan, dapat disimpulkan bahwa dari sistem pembinaan prestasi cabang olahraga menembak di Provinsi Riau sudah berjalan cukup baik dimana prestasi yang didapat tidak hanya tingkat nasional namun juga internasional. namun terdapat kendala dibagian pendanaan serta sarana dan prasarana. Dengan adanya penelitian ini diharapkan akan adanya perubahan tidak hanya pada cabang olahraga menembak tetapi juga olahraga lain khususnya di Provinsi Riau.
\end{abstract}

Kata Kunci: pembinaan prestasi, menembak, atlet, riau

\section{Performance development system for shooting sports athletes perbakin in the province of riau}

\begin{abstract}
This study aims to determine the performance development system for shooting sports athletes Indonesian Shooting Association in Riau Province. The research method used is descriptive quantitative. Research subjects totaling 14 people. The instruments used were observation, interview and questionnaire techniques which were conducted online. From the results of the research that has been carried out, it can be concluded that the system of fostering the achievement of the shooting sport in Riau Province has run quite well where the achievements are not only at the national level but also internationally. However, there are obstacles in the funding and facilities and infrastructure sectors. With this research, it is hoped that there will be changes not only in the shooting sport but also in other sports, especially in Riau Province.
\end{abstract}

Keywords: achievement coaching, shooting, athlete, riau

How To Cite: Saraswara, B. S., Ramadi., \& Vai, A. (2020). Sistem pembinaan prestasi atlet cabang olahraga menembak perbakin di provinsi riau. Journal of Sport Education (JOPE), 3 (1), 26-34.

\section{PENDAHULUAN}

Menembak merupakan olahraga terukur yang dapat melatih seseorang untuk berkonsentrasi, mengendalikan diri serta mampu untuk mengambil keputusan secara cepat dan tepat (Kamseno, 2016). Terdapat manfaat yang didapat dengan menekuni olahraga menembak, antara lain: 1) dapat melatih 
konsentrasi, ketepatan dan kecepatan, 2) melatih mental dan keberanian untuk dapat mengambil keputusan secara cepat dan tepat, 3) dapat melatih kesabaran, 4) dapat menjadi sarana untuk merilekskan tubuh setelah melakukan aktivitas (Vipassiwan, 2018).

Pada setiap cabang olahraga yang ada biasanya ada pembinaan yang diterapkan selama proses latihan maupun pertandingan berlangsung. Pembinaan prestasi adalah suatu tindakan atau usaha yang dilakukan secara maksimal untuk menumbuhkan atau meningkatkan pencapaian prestasi atlet dalam bidang olahraga. Terdapat 3 tahap pembinaan prestasi yang sesuai dengan piramida sistem pembinaan olaharaga yaitu melalui tahap pemassalan, pembibitan, dan peningkatan prestasi (Nugraha, 2019).

Beberapa hal yang mempengaruhi pembinaan prestasi antara lain (1) faktor internal yang mencakup: Kepribadian atlet, Kondisi fisik, Keterampilan teknik, Keterampilan taktis, dan Kemampuan mental. Sedangkan (2) faktor eksternal mencakup: penyediaan Sarana dan Prasarana, adanya Sumber daya manusia yang berkualitas, dan Pendanaan (Laksana, 2017).

Sarana dan prasarana merupakan hal dasar yang dibutuhkan dalam sebuah olahraga. Penyediaan sarana dan prasarana bagi pembinaan prestasi baik ditingkat nasional maupun daerah yang merupakan bagian integral dari keberhasilan pembinaan prestasi olahraga (Wibowo dan Hidayatullah, 2017). Standarisasi sarana dan prasarana sesuai standar dunia setiap cabang olahraga sangat penting karena berpengaruh terhadap kualitas alat yang digunakan dalam latihan.
Organisasi olahraga dan sumber daya manusia yang dimiliki suatu daerah menempati kedudukan paling utama dan penting diantara sumber daya lainnya dalam peningkatan prestasi olahraga. Komponen sumber daya manusia yang paling utama dalam bidang olahraga yaitu atlet, pelatih, wasit, serta pengurus (Nugraheni, 2017). Tidak hanya itu, pendanaan olahraga juga merupakan salahsatu faktor yang mempengaruhi pembinaan prestasi (Setyawati, 2013). Dimana pendanaan merupakan tanggung jawab bersama antara Pemerintah, Daerah, dan masyarakat. Pemerintah sebagai pengambil kebijakan tidak bisa terlepas dari aspek pendanaan dalam dunia olahraga.

Dalam olahraga menembak di Provinsi Riau pun juga dibutuhkan pembinaan olahraga untuk mencapai prestasi yang maksimal. Penelitian ini berguna untuk mengetahui sistem pembinaan prestasi pada cabang olahraga menembak PERBAKIN di Provinsi Riau sudah berjalan dengan baik atau belum. Jika terdapat kendala, maka diperlukan perbaikan dalam penerapan pembinaan prestasi pada cabang olahraga menembak PERBAKIN di Provinsi Riau sehingga sistem tersebut bisa diterapkan didaerah lain pada cabang olahraga yang sama.

\section{METODE}

\section{Jenis Penelitian}

Penelitian ini merupakan penelitian deskriptif. Penelitian deskriptif adalah penelitian yang berusaha mendeskripsikan suatu gejala, peristiwa, kejadian yang terjadi pada saat 
sekarang (Prastowo, 2014). Penelitian ini menggunakan penelitian deskriptif kuantitatif dimana untuk mengetahui tingkat sistem pembinaan prestasi atlet cabang olahraga menembak di Provinsi Riau.

\section{Populasi dan Sampel}

Populasi merupakan bagian dari subyek atau obyek yang memiliki ciri-ciri tertentu yang ditetapkan peneliti untuk ditarik kesimpulannya (Sugiyono, 2017). Populasi penelitian ini adalah 1 orang pengurus PERBAKIN di Provinsi Riau, 3 orang pelatih dan 10 orang atlet menembak di Provinsi Riau sehingga berjumlah 14 orang. Sampel adalah bagian dari jumlah populasi tersebut (Sugiyono, 2017). Teknik pengambilan sampel yaitu total sampling atau keseluruhan populasi, mengingat populasi relatif kurang dari 100. (Arikunto, 2006).

\section{Instrumen Penelitian}

Dalam penelitian ini data dilakukan dengan pengamatan langsung terhadap sampel dan juga berdasarkan bukti-bukti laporan maupun dokumentasi yang sudah ada. Teknik pengumpulan data pada penelitian menggunakan metode observasi, wawancara (interview) dan angket yang diberikan kepada sampel secara daring. Alat atau instrumen yang digunakan dalam wawancara yaitu pedoman wawancara dang angket diadopsi dari penelitian yang relevan yang berjudul "Pembinaan Prestasi Cabang Olahraga Tenis Lapangan di Kabupaten Sleman Tahun 2015" (Mulaksito, 2015). Pada angket disebarkan kepada 10 orang atlet yang terdiri dari 50 pernyataan dari 5 indikator yaitu atlet, pengurus, pelatih, sarana dan prasarana serta pendanaan. Sedangkan wawancara diberikan atas dua sudut pandang yaitu 1 orang pengurus dan 3 orang pelatih dimana untuk pertanyaan yang diberikan adalah sebagai berikut:

Pengurus, Bagaimana pendapat ibu/bapak mengenai atlet menembak di Provinsi Riau?; Bagaimana kondisi sarana dan prasarana yang ada?; Bagaimana struktur kepengurusan dalam organisasi ini?; Adakah kendala dalam organisasi yang dijalankan?; Menurut ibu/bapak apakah pembinaan prestasi atlet sudah sesuai standar?

Pelatih, Bagaimana pendapat ibu/bapak mengenai atlet menembak di Provinsi Riau?; Menurut ibu/bapak bagaimana kondisi fisik atlet menembak disini?; Bagaimana kedisiplinan para atlet dan bagaimana cara anda menerapkan kedisiplinan kepada mereka?Bagaimana kondis; i sarana dan prasarana yang ada?; Bagaimana tanggapan ibu/bapak perihal kepengurusan dalam organisasi ini?; Apakah manajemen dalam organisasi ini berjalan dengan baik?; Bagaimana pendapat ibu/bapak tentang pendanaan yang diberikan kepada atlet selama latihan/pertandingan?.

\section{HASIL DAN PEMBAHASAN}

Berdasarkan hasil penelitian yang sudah dilakukan peneliti menyajikan data yang merupakan hasil dari penelitian di lokasi penelitian yaitu di kantor PERBAKIN Jl. Dr. Setia Budhi No. 66, Pesisir, Lima Puluh, Kota Pekanbaru, Provinsi Riau dengan menggunakan sistem daring (online). Dalam penelitian ini, peneliti mengambil sebanyak 
10 sampel atlet menembak di Provinsi Riau sebagai responden untuk mengisi angket (kuisioner) penelitian. Selain itu juga peneliti mewawancarai 3 orang pelatih dan 1orang pengurus untuk mendapatkan data yang mendukung mengenai penelitian ini.

Menurut Suharsimi Arikunto (Salim, 2015) adapun tolak ukur untuk penelitian ini adalah sebagai berikut:

a. Apabila responden menjawab sangat setuju + setuju berada pada rentang $75,01 \%$ -
$100 \%=$ "Sangat Baik"

b. Apabila responden menjawab sangat setuju + setuju berada pada rentang 50,01\% $75 \%=$ "Baik"

c. Apabila responden menjawab sangat setuju + setuju berada pada rentang $25,01 \%$ $50 \%=$ "Cukup Baik"

d. Apabila responden menjawab sangat setuju + setuju berada pada rentang 0,00\% $25 \% \quad=\quad$ "Tidak Baik"

\section{Tabel 1. Rekapitulasi Data Berdasarkan Indikator Atlet}

\begin{tabular}{ccc}
\hline $\begin{array}{c}\text { Alternatif } \\
\text { Jawaban }\end{array}$ & $\begin{array}{c}\text { Rata-rata } \\
\text { Persentase jawaban }\end{array}$ & $\begin{array}{c}\text { Jumlah frekuensi } \\
\text { Jawaban }\end{array}$ \\
\hline Sangat Setuju & $66,7 \%$ & 100 \\
\hline Setuju & $32 \%$ & 48 \\
\hline Tidak Setuju & $13 \%$ & 20 \\
\hline Sangat Tidak Setuju & $0 \%$ & 0 \\
\hline
\end{tabular}

Sumber: Data Olahan Tahun 2020

Berdasarkan tabel 1 diatas dapat dijelaskan pelatih berdasarkan teori Suharsimi Arikunto bahwa distribusi frekuensi indikator atlet, berada pada kategori "Sangat Baik".

pilihan jawaban terbanyak yaitu sangat setuju dengan persentase $66,7 \%$ berarti indikator

Tabel 2. Rekapitulasi Data Berdasarkan Indikator Pelatih

\begin{tabular}{ccc}
\hline $\begin{array}{c}\text { Alternatif } \\
\text { Jawaban }\end{array}$ & $\begin{array}{c}\text { Rata-rata } \\
\text { Persentase jawaban }\end{array}$ & $\begin{array}{c}\text { Jumlah frekuensi } \\
\text { Jawaban }\end{array}$ \\
\hline Sangat Setuju & $52,5 \%$ & 84 \\
\hline Setuju & $33,7 \%$ & 54 \\
\hline Tidak Setuju & $6,8 \%$ & 11 \\
\hline Sangat Tidak Setuju & $6,8 \%$ & 11 \\
\hline
\end{tabular}

Sumber : Data Olahan Tahun 2020

Berdasarkan tabel 2 diatas dapat dijelaskan dengan persentase $52,2 \%$ berarti indikator bahwa distribusi frekuensi indikator Pelatih, pilihan jawaban terbanyak yaitu setuju berada pada kategori "Sangat Baik".

Tabel 3. Rekapitulasi Data Berdasarkan Indikator Sarana dan Prasarana

\begin{tabular}{ccc}
\hline $\begin{array}{c}\text { Alternatif } \\
\text { Jawaban }\end{array}$ & $\begin{array}{c}\text { Rata-rata } \\
\text { Persentase jawaban }\end{array}$ & $\begin{array}{c}\text { Jumlah frekuensi } \\
\text { Jawaban }\end{array}$ \\
\hline Sangat Setuju & $26 \%$ & 13 \\
\hline Setuju & $50 \%$ & 25 \\
\hline Tidak Setuju & $20 \%$ & 10 \\
\hline Sangat Tidak Setuju & $4 \%$ & 2 \\
\hline
\end{tabular}

Sumber: Data Olahan Tahun 2020 
Berdasarkan tabel 3 diatas dapat dijelaskan indikator sarana dan prasarana berdasarkan bahwa distribusi frekuensi indikator sarana teori Suharsimi Arikunto berada pada kategori dan prasarana, pilihan jawaban terbanyak "Sangat Baik".

yaitu setuju dengan persentase $50 \%$ berarti

Tabel 4. Rekapitulasi Data Berdasarkan Indiktor Organisasi

\begin{tabular}{ccc}
\hline $\begin{array}{c}\text { Alternatif } \\
\text { Jawaban }\end{array}$ & $\begin{array}{c}\text { Rata-rata } \\
\text { Persentase jawaban }\end{array}$ & $\begin{array}{c}\text { Jumlah frekuensi } \\
\text { Jawaban }\end{array}$ \\
\hline Sangat Setuju & $21,1 \%$ & 19 \\
\hline Setuju & $37,8 \%$ & 34 \\
\hline Tidak Setuju & $43,3 \%$ & 39 \\
\hline Sangat Tidak Setuju & $5,6 \%$ & 5 \\
\hline
\end{tabular}

Sumber: Data Olahan Tahun 2020

Berdasarkan tabel 4 diatas dapat dijelaskan indikator organisasi berdasarkan teori bahwa distribusi frekuensi indikator Suharsimi Arikunto berada pada kategori organisasi, pilihan jawaban terbanyak yaitu "Cukup Baik".

tidak setuju dengan persentase $43,3 \%$ berarti

Tabel 5. Rekapitulasi Data Berdasarkan Indikator Pendanaan

\begin{tabular}{ccc}
\hline $\begin{array}{c}\text { Alternatif } \\
\text { Jawaban }\end{array}$ & $\begin{array}{c}\text { Rata-rata } \\
\text { Persentase jawaban }\end{array}$ & $\begin{array}{c}\text { Jumlah frekuensi } \\
\text { Jawaban }\end{array}$ \\
\hline Sangat Setuju & $10 \%$ & 5 \\
\hline Setuju & $44 \%$ & 22 \\
\hline Tidak Setuju & $38 \%$ & 19 \\
\hline Sangat Tidak Setuju & $8 \%$ & 4 \\
\hline
\end{tabular}

Sumber: Data Olahan Tahun 2020

Berdasarkan tabel 4 diatas dapat dijelaskan indikator organisasi berdasarkan teori bahwa distribusi frekuensi indikator Suharsimi Arikunto berada pada kategori organisasi, pilihan jawaban terbanyak yaitu "Cukup Baik".

tidak setuju dengan persentase $43,3 \%$ berarti

Tabel 6. Rekapitulasi Data Berdasarkan Keseluruhan Indikator

\begin{tabular}{ccc}
\hline $\begin{array}{c}\text { Alternatif } \\
\text { Jawaban }\end{array}$ & $\begin{array}{c}\text { Rata-rata } \\
\text { Persentase jawaban }\end{array}$ & $\begin{array}{c}\text { Jumlah frekuensi } \\
\text { Jawaban }\end{array}$ \\
\hline Sangat Setuju & $44,2 \%$ & 221 \\
\hline Setuju & $36,4 \%$ & 182 \\
\hline Tidak Setuju & $15,2 \%$ & 76 \\
\hline Sangat Tidak Setuju & $4,4 \%$ & 22 \\
\hline
\end{tabular}

Sumber: Data Olahan Tahun 2020

Dari sudut pandang pelatih dan pengurus yang dimana data didapatkan berdasarkan hasil wawancara daring (online) untuk pembinaan prestasi menembak di Provinsi Riau sudah berjalan cukup baik namun ada kendala pada sarana dan prasarana serta pendanaan yang mendapat kurang perhatian

dari pemerintah daerah. Venue menembak yang tersedia hanya lapangan 10 meter air pistol dan air rifle sedangkan untuk nomor senjata api menggunakan lapangan yang ada di Sekolah Polisi Negara di Pekanbaru. Dana yang digunakan untuk pembelian senjata, amunisi dan target juga masih menggunakan 


\section{Journal of Sport Education (JOPE), 3 (1) 2020 - 31}

Bella Shasi Saraswara ${ }^{1}$, Ramadi $^{2}$, Aref Vai $^{3}$

dana pribadi atlet. Berdasarkan hasil

Berdasarkan hasil wawancara pada penelitian yang sudah disampaikan pada bab hasil dapat diberikan penjelasan lebih lanjut terkait dengan Sistem Pembinaan Prestasi Atlet Cabang Olahraga Menembak PERBAKIN Di Provinsi Riau. Diketahui bahwa responden cenderung menjawab pernyataan pada indikator atlet didapatkan hasil terbesar kategori sangat setuju yaitu 66,7 $\%$. Pada indikator pelatih didapatkan hasil kategori sangat setuju yaitu 52,5\%. Pada indikator sarana dan prasarana didapatkan hasil kategori setuju yaitu 50,0\%. Pada indikator pengurus/organisasi didapatkan hasil kategori tidak setuju yaitu 43,3\%. Dan pada indikator pendanaan didapatkan hasil kategori setuju yaitu $44 \%$.

Dari sudut pandang atlet dari hasil rekapitulasi data diatas yang didapat adalah responden menjawab sangat setuju (SS) sebanyak $44,2 \%$, Setuju (S) sebanyak $36,4 \%$, Tidak Setuju (TS) sebanyak 15,2\% dan Sangat Tidak Setuju (STS) sebanyak 4,4\%, maka hasil yang didapat dari rekapitulasi diatas yaitu $44,2 \%+36,4 \%=80,6 \%$.

Dapat disimpulkan bahwa Sistem Pembinaan Prestasi Atlet Cabang Olahraga Menembak PERBAKIN Di Provinsi Riau termasuk dalam kategori Sangat Baik.

\section{Hasil Wawancara Sudut Pandang Pengurus}

Hasil wawancara yang dilakukan kepada 1 orang pengurus didapatkan hasil sesuai dengan pernyataan yang diajukan yaitu sebagai berikut:

Perkembangan atlet menembak di Provinsi Riau

pernyataan diatas, pengurus mengatakan cabang olahraga menembak di Provinsi Riau sudah berkembang dengan pesat dimana terhitung 23 club menembak yang ada di Provinsi Riau sehingga memudahkan pelatih dalam pencarian bibit atlet tidak hanya pada bidang target saja tapi juga dibidang berburu.

Kondisi Sarana dan Prasarana Cabang Olahraga Menembak Di Provinsi Riau

Berdasarkan hasil wawancara pada pernyataan diatas, pengurus menyebutkan sarana dan prasarana yang ada hanya lapangan 10 meter Airpistol dan 10 meter Airirffle milik Pengurus Provinsi dan Pengurus Kabupaten Dumai, sedangkan nomor pertandingan yang menggunakan senjata api masih menggunakan lapangan Brimob dan Sekolah Polisi Negara (SPN) di Pekanbaru.

\section{Struktur Kepengurusan yang Dijalankan}

Berdasarkan hasil wawancara pengurus pada pernyataan diatas, kepengurusan PERBAKIN di Provinsi Riau sudah berjalan dengan baik dalam bidang target maupun berburu.

\section{Standar yang Diterapkan Dalam Pembinaan Prestasi Cabang Olahraga Menembak Di Riau}

Berdasarkan dari hasil wawancara pengurus pada pernyataan diatas, bahwa pembinaan prestasi cabang olahraga menembak di Provinsi Riau sudah dijalankan sesuai standar dibktian dengan prestasi yang diraih oleh atlet tidak hanya di tingkat nasional namun juga ditingkat internasional.

Hasil Wawancara Sudut Pandang Pelatih Perkembangan Atlet Menembak di 


\section{Journal of Sport Education (JOPE), 3 (1) 2020 - 32}

Bella Shasi Saraswara ${ }^{1}$, Ramadi $^{2}$, Aref Vai $^{3}$

\section{Provinsi Riau}

Berdasarkan hasil Wawancara yang dirangkum dari 3 pelatih menembak di Provinsi riau sesuai dengan pernyataan diatas yaitu club menembak sudah mendapat perhatian dari beberapa daerah di Provinsi Riau pada bidang target salah satunya Bono Shooting Club dari Kabupaten Pelalawan yang mengikuti ajang PORKOT yang diadakan beberapa waktu lalu.

\section{Kondisi Fisik Atlet Menembak Di Provinsi}

Riau

Dirangkum dari wawancara 3 orang pelatih menembak Provinsi Riau menyatakan untuk kondisi fisik atlet bias dikatakan cukup baik karena didukung dengan adanya peran pelatih.

Pengadaan Sarana dan Prasarana Cabang Olahraga Menembak Di Provinsi Riau

Berdasarkan hasil rangkuman pernyataan dari 3 pelatih didapatkan informasi bahwa kurang adanya perhatian dari pemerintah daerah dimana peralatan dan lapangan disediakan oleh masing-masing club menembk misalnya untuk pemula, senjata digunakan secara bergantian sedangkan dalam penggunaan seharusnya tiap individu memiliki senjata pribadi.

\section{Pendanaan Terhadap Atlet Menembak}

\section{Provinsi Riau}

Untuk pernyataan diatas dimana dirangkum berdasarkan pendapat 3 orang pelatih bahwa pada pendaan masih terdapat kendala dimana dana hanya diberikan kepada atlet yang berprestasi padahal proses latihan yang membutuhkan contohnya amunisi dan target juga memerlukan biaya yang cukup besar.
Dari penjelasan diatas dapat dikatakan bahwa idealnya, sarana dan prasarana merupakan salah satu pendukung prestasi yang perlu dilakukan pengadaaan. Hal ini sesuai dengan apa yang disampaikan oleh (Triyasari, 2016) bahwa kemampuan pelatih, sarana dan prasarana, serta kondisi lingkungan pembinaan merupakan salah satu strategi pembinaan olahraga. Terkait dengan apa yang terjadi pada sistem pembinaan prestasi menembak di Riau, hal itu perlu menjadi perhatian lebih lanjut. Perlu adanya campur tangan pengprov riau unuk mengatasi hal tersebut. Hal ini sesuai dengan pendapat (Parena, 2017) yang menyatakan bahwa perlunya lembaga keolahragaan ataupun lembaga yang memiliki kewenangan dalam penyediaan sarana dan prasarana dan pendanaan olahraga demi mendukung tercapainya prestasi yang optimal.

Namun, dengan adanya permasalahan pada pembinaan prestasi yang dijalankan tidak menghentikan semangat atlet untuk berprestasi dibuktikan dengan perolehan prestasi tidak hanya di tingkat nasional namun juga internasional.Perbedaan pendapat dari sudut pandang atlet yang dilihat dari tabel 3 yang menyatakan bahwa sarana dan prasarana sudah sangat baik dikarenakan atlet hanya fokus pada proses latihan sehingga mendapatkan prestasi yang maksimal.

\section{SIMPULAN}

Berdasarkan hasil penelitian ini maka dapat disimpulkan bahwa dalam sudut pandang atlet berada pada persentase $80,6 \%$ berada dalam kategori "Sangat Baik", sedangkan 
Journal of Sport Education (JOPE), 3 (1) 2020 - 33

Bella Shasi Saraswara ${ }^{1}$, Ramadi ${ }^{2}$, Aref Vai ${ }^{3}$

dari sudut pandang pelatih dan pengurus melalui wawancara sistem daring (online) berada pada kategori "cukup baik". Dengan adanya penelitian Sistem Pembinaan Prestasi Atlet Cabang Olahraga Menembak PERBAKIN Di Provinsi Riau, peneliti berharap adanya perubahan tidak hanya pada cabang olahraga menembak tapi juga cabang olahraga lain khususnya di Provinsi Riau.

\section{DAFTAR PUSTAKA}

Arikunto, Suharsimi. (2006). Prosedur Penelitian Suatu Pendekatan Praktik.

Jakarta : Rineka Cipta

Gustopo Bayu Laksana, H. P. \& S. B. M.

(2017). Perspektif Olahraga Petanque dalam Mendukung Prestasi Olahraga Jawa Tengah. Physical Education and Sports, 6(1), 36-43.

Kamseno, S., Sujiono, B., \& Apriyanto, T. (2016). Upaya Peningkatan Kemampuan Menembak Air Rifle 10 Meter Dengan Berlatih Keseimbangan Pada Siswa Latihan Lanjutan Menembak ( LLM ). Jurnal Ilmiah Sport Coaching and Education, 2(2), 75-85.

Nugraheni, A. R., Rahayu, S., \& Handayani,

O. W. K. (2017). Evaluasi Pembinaan

Olahraga Prestasi Bola Voli Pantai

Puteri Klub Ivojo (Ikatan Voli

Ngembalrejo) di Kabupaten Kudus

Tahun 2016. Journal of Physical

Education and Sports, 6(3), 225-231.

Parena, A. A., Rahayu, T., \& Sugiharto.

(2017). Manajemen Program Pembinaan

Olahraga Panahan pada Pusat

Pendidikan dan Latihan Pelajar (PPLP)
Provinsi Jawa Tengah. Journal of

Physical Education and Sports, 6(1), 16.

Prastowo, Andi. (2014). Memahami Metode Penelitian. Yogyakarta: Ar-Ruzz Media

Pratama Dharmika Nugraha, E. B. P. (2019). Survei Pembinaan Prestasi Atlet Bolabasket Kelompok Umur Di Bawah 16 Dan 18 Tahun. Journal Sport Area, 4(1), 240-247.

Saiful, M. A., Dra, U., Setyawati, H., Si, M., Yuwono, D. C., \& Pd, M. (2013). Pembinaan Olahraga Bela Diri Wushu Di Kota Salatiga Tahun 2013. Active Journal of Physical Education, Sport, Health and Recreation, 2(10), 624-629.

Sugiyono. (2017). Metode Penelitian Kualitatif, Kuantitatif dan $R \& D$. Bandung : Alfabeta

Triyasari, A., K.S, S., \& Soekardi. (2016). Evaluasi Pembinaan Olahraga Senam Artistik Di Klub Senam Kabupaten Pati Dan Kabupaten Rembang. Journal of Physical Education and Sport, 5(1), 4146.

Vipassiwan, S., Sulaiman, I., \& Sujiono, B. (2018). Pengembangan Model Latihan Dengan Permainan Dalam Olahraga Menembak Pada Anggota Klub Olahraga Prestasi Menembak Universitas Negeri Jakarta. Jurnal Ilmiah Sport Coaching and Education, 2(2), 138-149.

Wibowo, K., \& Hidayatullah, M. F. (2017). Evaluasi Pembinaan Prestasi Olahraga Bola Basket di Kabupaten Magetan. 
Journal of Sport Education (JOPE), 3 (1) 2020 - 34

Bella Shasi Saraswara ${ }^{1}$, Ramadi $^{2}$, Aref Vai ${ }^{3}$

l(1), 39-48. 